Santiago, WD, Borges, CN, Barbosa, RB, Mendonça, HA, Nelson, DL \& Cardoso, MG. (2020). Investigation of brazilian cachaças regarding their standardization and quality. Research, Society and Development, 9(7): 1-21, e387974117.

\title{
Investigação sobre cachaças brasileiras quanto a sua padronização e qualidade
}

Investigation of brazilian cachaças regarding their standardization and quality

Investigación sobre las cachazas brasileñas en cuanto a su estandarización y calidad

Recebido: 30/04/2020 | Revisado: 04/05/2020 | Aceito: 09/05/2020 | Publicado: 18/05/2020

\section{Wilder Douglas Santiago}

ORCID: http://orcid.org/0000-0003-4941-2527

Universidade Federal de Lavras, Brasil

E-mail: wilder.dsantiago@ufla.br

Cleber Nogueira Borges

ORCID: http://orcid.org/0000-0001-9707-2913

Universidade Federal de Lavras, Brasil E-mail: cleber.borges@ufla.br

Richard Bispo Barbosa

ORCID: http://orcid.org/0000-0002-1358-0257

Universidade Federal de Lavras, Brasil

E-mail: richardbispo2009@hotmail.com

Hélia Alves Mendonça

ORCID: http://orcid.org/0000-0001-8547-5897

Ministério da Agricultura Pecuária e Abastecimento, Brasil

E-mail: helia_alvesm@yahoo.com.br

David Lee Nelson

ORCID: http://orcid.org/0000-0001-7435-3675

Universidade Federal dos Vales do Jequitinhonha e Mucuri, Brasil

E-mail: dlnelson@ufmg.br

Maria das Graças Cardoso

ORCID: http://orcid.org/0000-0001-8075-1725

Universidade Federal de Lavras, Brasil

E-mail: mcardoso@ufla.br 


\title{
Resumo
}

Incluir o resumo. $\mathrm{O}$ agronegócio da cachaça é uma prática representativa no mercado brasileiro. Estima-se que o setor produza anualmente 1,3 bilhão de litros da bebida, tendo um total de 30 mil estabelecimentos produtores, gerando mais de 450 mil empregos diretos e indiretos. O processo produtivo da cachaça se estabelece em quase todos os estados brasileiros, sendo os principais estados produtores São Paulo, Pernambuco, Ceará, Rio de Janeiro, Goiás e Minas Gerais, que respondem por cerca de $75 \%$ da produção nacional. A cadeia produtiva da cachaça no país não é homogênea, mesmo pela tradição e pela importância econômica desta bebida no país. Buscam-se melhorias no desenvolvimento de tecnologias para aperfeiçoar e controlar a qualidade e a padronização da bebida nos aspectos físico-químicos e sensoriais. Assim, o objetivo deste trabalho foi identificar a similaridade das variáveis determinantes da qualidade das cachaças produzidas em nosso país utilizando a técnica da análise de agrupamento multivariada. Foram coletadas 512 amostras, onde suas análises físico-químicas foram aplicadas na análise multivariada. Pelos resultados foi possível observar que $70 \%$ das amostras estudadas apresentam padrões de identidade e qualidade exigidos pelo Ministério da Agricultura Pecuária e Abastecimento (MAPA). Todos os parâmetros analisados apresentaram resultados de inconformidade frente a legislação. Com a Análise das Componentes Principais (PCA) aplicada, foi possível observar uma homogeneidade quanto ao processo produtivo em relação ao perfil físico-químico realizado nas amostras. De maneira geral é possível inferir que o processo produtivo da cachaça está sendo satisfatório, porem muita coisa pode ser melhorada em relação ao comercio e na padronização das cachaças brasileiras.

Palavras-chave: Cana de açúcar; Controle de qualidade; Bebidas; Contaminantes.

\begin{abstract}
The cachaça agribusiness is a representative practice in the Brazilian market. It is estimated that the sector produces 1.3 billion liters of beverage annually, and a total of 30,000 producing establishments generate more than 450.000 direct and indirect jobs. The cachaça production process is established in almost all Brazilian states, where the main producing states are São Paulo, Pernambuco, Ceará, Rio de Janeiro, Goiás and Minas Gerais, which account for about $75 \%$ of the national production. The cachaça production chain in the country is not homogeneous, in spite of the tradition and the economic importance of this beverage in the country. Improvements are sought in the development of technologies to improve and control
\end{abstract}


the physicochemical and sensory aspects of the quality and standardization of the beverage. Thus, the objective of this work was to identify the similarity of the variables that determine the quality of cachaça produced in Brazil using multivariate cluster analysis. We collected 512 samples, and their physicochemical analyses were applied in multivariate analysis. Of the samples, $70 \%$ presented identity and quality standards required by the ABPM. All the results for the parameters analyzed were non-compliant with the legislation. With the PCA applied, a homogeneity in the production process with respect to the physicochemical profile was observed in the samples. In general, the production of cachaça can be inferred as being satisfactory, but much can be improved with respect to commercialization and standardization of Brazilian cachaça.

Keywords: Sugar cane; Quality control; Drinks; Contaminants.

\section{Resumen}

El agronegocio de la cachaza es una práctica representativa en el mercado brasileño. Se estima que este sector produce anualmente 1,3 billones de litros de esta bebida, con un total de 30 mil establecimientos productores, generando más de 450 mil empleos directos e indirectos. La producción está presente en casi todos los estados, en donde São Paulo, Pernambuco, Ceará, Rio de Janeiro, Goiás y Minas Gerais son responsables de alrededor del $75 \%$ de la producción nacional. La cadena productiva de la cachaza no es homogénea, a pesar de que esta bebida es tradicional y tiene importancia económica en el país. Entonces se buscan mejoras en el desarrollo de tecnologías para mejorar y controlar la calidad y la estandarización de los aspectos fisicoquímicos y sensoriales de la bebida. Por lo tanto, el objetivo de este trabajo fue identificar, mediante un análisis cluster, la similitud de las variables determinantes de la calidad de las cachazas producidas en Brasil. Se colectaron 512 muestras, cuyos análisis fisicoquímicos fueron sometidos a un análisis multivariado. El 70\% de las muestras presentaron patrones de identidad y calidad exigidos por el MAPA. Todos los resultados de los parámetros analizados no cumplían con la legislación. El análisis con PCA permitió observar una homogeneidad en el proceso productivo en relación al perfil fisicoquímico de las muestras. De manera general es posible inferir que el proceso productivo de la cachaza está siendo satisfactorio, sin embargo, se puede mejorar mucho en cuanto al comercio y la estandarización de la cachaza en Brasil.

Palabras clave: Caña de azúcar; Control de calidad; Bebidas; Contaminantes. 


\section{Introduction}

Being typically Brazilian, cachaça originates from the beginning of Brazil's formation with the introduction of sugarcane crops by the Portuguese, and it is recognized both for its contributions and influences in Brazilian culture, in the country's current economy and in the international market. Several high-quality brands of cachaça currently appear in the national and international markets, and they are present in the best restaurants and residential wine cellars in Brazil and in the world. Cachaça ceased to be a beverage of the poor, and now has a prominent place in the national toasts, in feasts and among foreigners. It has earned its own name abroad - "Cachaça do Brasil" — and it is supported by various government plans and projects for its expansion nationally and internationally. It is currently a product consumed by all social classes, so a better-quality product is required. Numerous studies have been performed to improve both the quality of the raw material, the sugarcane varieties, and the care taken during the production of the beverage, as well as the control of contaminating compounds (Cardoso, 2013).

According to Normative Instruction No. 13 of June 30, 2005, sugarcane spirit is a beverage with an alcoholic strength of 38 to $54 \% \mathrm{v} / \mathrm{v}$ at $20{ }^{\circ} \mathrm{C}$, obtained as the simple alcoholic distillate from sugarcane or by distillation of the fermented must of the sugarcane juice, and as much as $6 \mathrm{~g} \mathrm{~L}^{-1}$ of sugars, expressed as sucrose, can be added. Cachaça, however, is defined as being the sugarcane spirit that has an alcohol content between 38 and $48 \%$ by volume (Brasil, 2005a).

The cachaça agribusiness is a representative practice in the Brazilian market. According to the Brazilian Cachaça Institute (IBRAC), it is estimated that the national production of sugarcane cachaça is approximately 1.3 billion liters per year. This distillate has been moving in recent years, about $\$ 7.5$ billion annually, generating IPI, ICM and other taxes. Cachaça production is established in almost all Brazilian states, and the principal producing states are São Paulo, Pernambuco, Ceará, Rio de Janeiro, Goiás and Minas Gerais. These states account for about $75 \%$ of the national production. The State of Minas Gerais stands out in the alembic cachaça production, with an annual total of 250 million liters, which corresponds to $60 \%$ of the national production. In 2018, cachaça was exported to 77 countries by more than 50 exporting companies, generating revenues of US\$ 15.61 million (8.41 million liters). These figures represent a decrease of $1.24 \%$ in value and $3.80 \%$ in volume compared to 2017, and the main destination countries in terms of value were the United 
States, Germany, Paraguay, Portugal and Italy. Only $1 \%$ of the national production of cachaça is exported, the rest is directed to the domestic market. It is a product appreciated by all social classes, and it is of growing importance in the foreign market through the acceptance of its most famous beverage "the caipirinha". Thus, the demand to increase product quality is directly related to increased marketing. Despite the significant numbers, when taking the product home, consumers should be aware because $80 \%$ of the market is dominated by illegal producers who do not follow production standards, and, according to various researchers, consuming these products may pose a health risk. (Alcarde, 2017; Ibrac, 2019).

The cachaça production chain in the country is becoming more homogeneous. However, research has been performed to improve and control the quality and standardization of the beverage in the physicochemical and sensory aspects. A quality beverage must meet the Identity and Quality Standards (PIQ's) required by Brazilian law, as well as the sensory requirements that involve color, taste and aroma (Brasil, 2005a). And for this to happen, all stages of beverage production involving the preparation of raw material, the extraction of sugarcane juice, fermentation, distillation and aging must be properly controlled.

The characterization and comparison of various food products, such as breads, juices, wines, cachaça and other alcoholic beverages, has been analyzed using multivariate analysis. Such analysis has become an important tool for manipulating and interpreting data with many variables. Through this tool, it is possible to group similar variables, investigate the dependence between grouped variables, relate observed variables so as to predict one or more variables, and build hypothesis tests (Rencher, 2002; Nieuwoudt et al., 2004; Ferreira, 2015; Santiago et al., 2015; Gomes \& Cavalcante, 2017).

Principal Component Analysis (PCA) is one of the most widely used methods; it transforms a set of original correlated variables into a new set of uncorrelated variables called principal components. Through the PCA, it is possible to select characteristics with greater participation in each component and define the physicochemical characteristics of the beverages that should be monitored (Santiago et al., 2015; Gomes \& Cavalcante, 2017). Therefore, this study seeks to identify the similarity of the variables that determine the quality of cachaça produced in our country using the multivariate cluster analysis technique. 


\section{Material and Methods}

\section{Sampling and physicochemical analysis}

Research is done to bring new knowledge to society, as stated by Pereira et al. (2018). In present research, samples were purchased from different producing companies located in the main Brazilian producing states, and the beverages were produced from 2012 to 2016. The samples were selected according to the local of production of the beverages. A total of 512 samples (reports) were collected from physicochemical analyzes of the studied beverages performed in laboratories registered and recognized by the legislation.

The physicochemical analyses of these samples were performed at the Laboratory for Physicochemical Analyses of Spirits (LAFQA), Department of Chemistry of the Federal University of Lavras. These analyses were performed according to the specifications established by Normative Instruction No. 24 of September 08, 2005, of the Ministry of Agriculture, Livestock and Supply (MAPA) (Brasil, 2005b). The parameters analyzed were Organoleptic Exam (eorga), Relative Density (densi), Copper (cu), Dry Extract (eseco), Alcohol Concentration (gl), Volatile Acidity (avolatil), Superior Alcohols (asupe), n-Propyl Alcohol (prop1), Isobutyl Alcohol (isobutil), Isoamyl Alcohol (isoamili), Sec-Butyl Alcohol (butil2), Butyl Alcohol (butil1), Furfural (fur), Aldehyde (aldei), Esters (este), Sum of Secondary Components (soma) and Methyl Alcohol (met).

\section{Multivariate analysis}

Principal component analysis (PCA) was used to ascertain and understand the possible similarities between the samples regarding the analyzed parameters. PCAs were separately applied for the values of cachaça contaminants and secondary compounds. The separation occurred because of the fact that not all the samples presented complete results for all the parameters analyzed. After this separation, a new PCA was applied with all the parameters analyzed. The preprocessing use of the results was the self-scaling that consists of centering the data on the average and dividing them each by the standard deviation, so that all the variables have the same variance. The analysis was performed using the $\mathrm{R}$ program ( $\mathrm{R}$ Core Team, 2016). The PCA was performed by comparing the samples for the physicochemical and chromatographic analysis. 


\section{Results and Discussions}

The following percentages of the samples were outside the established limits for the parameters organoleptic examination, copper, dry extract, alcoholic degree, volatile acidity, total higher alcohols, butanol-2, butanol-1, aldehydes, esters, sum of secondary compounds, furfural and methanol, respectively: $8 \%, 8 \%, 3 \%, 12 \%, 7 \%, 2 \%, 5 \%, 4 \%, 4 \%, 1 \%, 15 \%, 3 \%$ and $2 \%$. Overall, $70 \%$ of the samples met the quality standards required by MAPA. The cachaça producers in this country appear to be using good manufacturing practices in their stills because the results were satisfactory regarding the analyzed compounds and such results corroborate most of the studies found in the literature (Pereira et al., 2003; Fernandes et al., 2007; Miranda, et al., 2007; Caruso et al., 2008; Santiago et al., 2015; Bortoletto \& Alcarde, 2015; Pellenz et al., 2017).

The self-scaling of results for multivariate analyses was performed. The following figures represent the analyses performed. Figure 1 represents the line graphs of the samples analyzed for the parameters of secondary compounds [eseco (Dry Extract), gl (Alcohol Concentration), avolatil (Volatile Acidity), asupe (Higher Alcohols), prop1 (Propyl Alcohol), isobutil (Isobutyl Alcohol), isoamili (Isoamyl Alcohol), aldei (Aldehyde) and este (Esters)]. 
Figure 1. Results of the physicochemical profile regarding the contaminant contents of the cachaças studied (author's source).

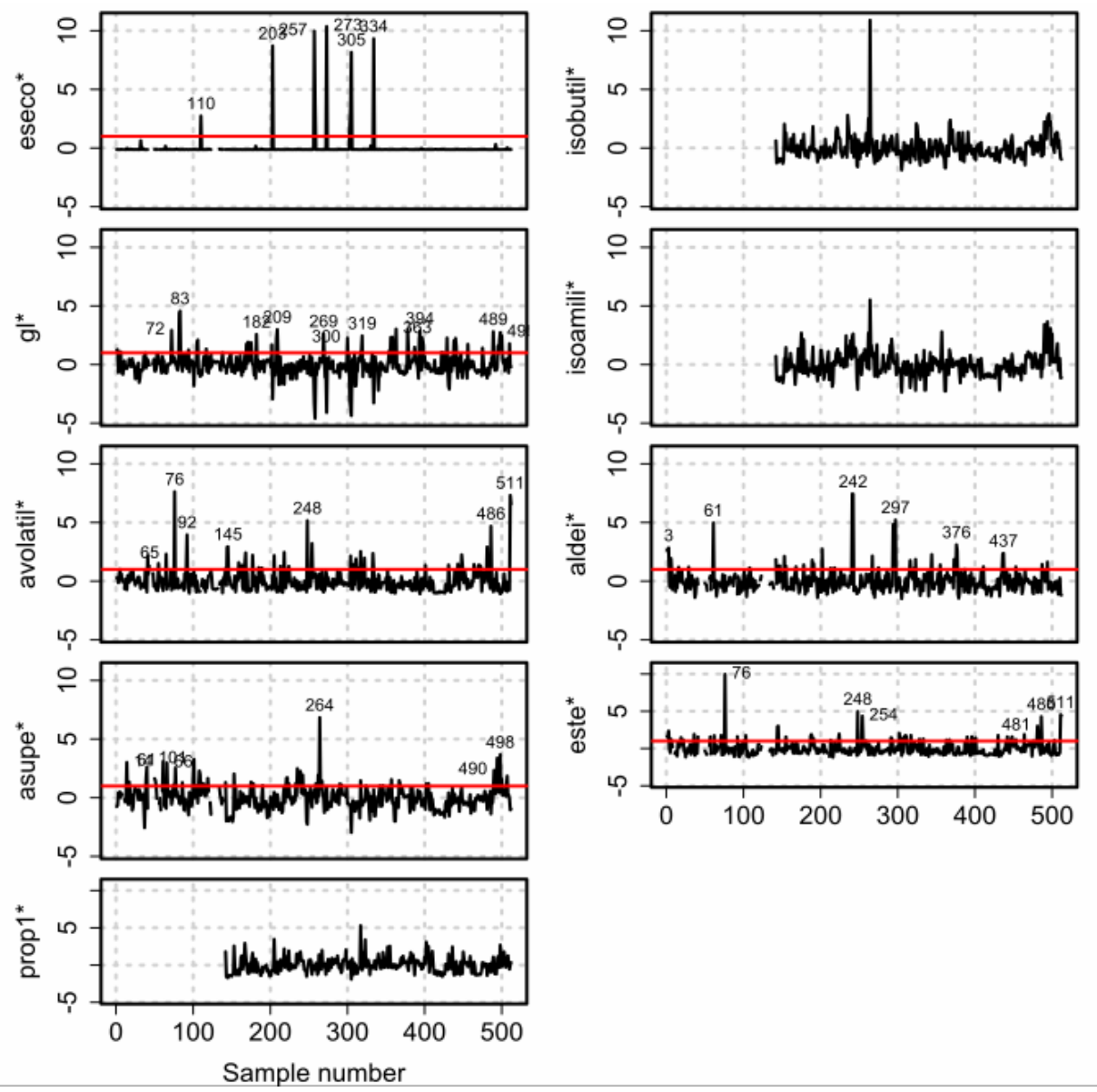

Source: Authors.

From the graphs (Figure 1), the compounds could be analyzed as to their standardization. Compounds with limits are represented in the graph by a red line, the value established by the legislation was also self-scaled and samples with limits were represented. Discontinuous lines can be seen because the corresponding parameter has not been evaluated in some samples. According to the self-scaled results, some samples were outside the limit established by MAPA for the parameters dry extract, alcohol content, volatile acidity, higher alcohols, aldehydes and esters.

According to the MAPA, there is no upper limit for dry extract. However, the limit of $6 \mathrm{~g} \mathrm{~L}^{-1}$, referring to the sucrose that can be added in cachaça and spirits, was drawn in the figure. The low value found might be related to beverages where the addition of sugar, natural fruit essences and artificial wood extracts might have been made because these additions are not well regarded by the legislation, much less by the consumer. Another factor that leads to 
an increase in the total dry extract in cachaça is the aging process, which consists of the storage of the beverage in wooden casks. According to Cardoso (2013), Santiago et al. (2014a) and Santiago et al. (2017), the longer the storage time for cachaça in wood, the greater the direct extraction of the components and, consequently, the increase in the dry extract content.

Miranda et al. (2008) and Santiago et al. (2017) explain that this increase in dry extract occurs as a result of the degradation of lignin by ethanol into aromatic compounds, leading to their incorporation into the beverage. These aromatic compounds are believed to be tannins and phenolic compounds, which represent up to $40 \%$ of the dry extract. Thus, the evolution of dry extract in aged beverages is proportional to the extraction of phenolic compounds and, consequently, the intensity of the color. In general, the aging process adds value to the beverage both economically and organoleptically, and it is, therefore, a positive practice in the production process. Although it is a practice among producers to add sugar and other compounds, as mentioned above, to beverages, a very low value for dry extract was observed, which leads to a concern of producers regarding the use of these practices.

A low nonconformity of values for alcohol content and volatile acidity was observed. The characterization of an alcoholic beverage is determined by the alcohol concentration, which is considered to be one of the parameters of great importance in beverages. According to Miranda et al. (2007) and Cardoso (2013), one of the causes for the low and high alcohol contents in cachaças might be the result of possible errors and inaccuracies in the equipment used by producers to determine the concentration and possible errors in the preparation of the product. Distillation or dilution directly affect the amount of this component in the cachaça. Losses along the aging process can also occur as a result of storage of the beverage in wooden barrels. Environmental conditions or the consumption of ethanol during acid esterification reactions during storage can also affect the concentration (Miranda et al., 2006: Cardoso, 2013; Santiago et al., 2017). Other factors responsible for non-conformities of alcohol content in alcoholic beverages can be related to the maturation process in stainless steel vats and the final filling of containers, where such processes can present non-conformity in the sealing of the containers.

Low values for the volatile acidity were also observed compared to the maximum limit allowed by the Brazilian legislation. The cachaça with a high acidity is sensorially unpleasant; However, the presence of these acidic compounds in small quantities is of great importance for the quality of the beverage because, during their production, the acids react with the alcohols present to form esters. The acidity results from the oxidation of ethanol and of some 
compounds extracted from wood, which contribute to the formation of acetaldehyde, which, in turn, leads to the formation of acetic acid (Cardoso, 2013; Santiago et al., 2016). Pereira et al. (2003) analyzed 45 samples of cachaça from different locations in the state of Minas Gerais, and the average value found for volatile acidity was $77.79 \mathrm{mg} 100 \mathrm{~mL}^{-1}$ of anhydrous alcohol. The acidities for three samples were outside the limits required by the legislation.

Like the other secondary compounds already mentioned, the concentrations of higher alcohols, aldehydes and esters were generally within the limits required by the legislation. Higher alcohols can be formed during the oxidative process, or they can be formed through transformations of amino acids during the fermentation process. Other factors that contribute to the high concentration of higher alcohols in cachaça are the high temperature used during the fermentation process and the very acidic $\mathrm{pH}$. Just as with the esters, in desirable quantity, the higher alcohols are responsible for the characteristic aroma and flavor of the beverages. The principal higher alcohols found in spirits are isoamyl (2-methylbutan-1-ol), amyl (pentan1-ol), isobutyl (2-methylpropan-1-ol) and propyl (propan-1-ol) alcohols (Vilela et al., 2007; Cardoso, 2013; Santiago et al., 2016). From the results presented, it would appear that the producers are being careful regarding the excessive formation of higher alcohols. Producers are taking care not to store sugarcane for a long time after cutting, avoiding amino acid degradation and subsequent formation of higher alcohols; they do not use cane left over from a previous season, or wash the cane after cutting, thereby preventing its contamination by bacteria, which can interfere in the performance of yeast during fermentation.

Aldehydes are formed by the action of yeast during preliminary stages of the fermentation process, and the main aldehyde formed is acetaldehyde. Other aldehydes can be formed in the fermentation process from the amino acids present in sugarcane juice. It is evident that the producers are cautious about the fermentation process, where greater contamination by aldehydes occurs when the wort undergoes excessive aeration, in which the higher alcohols undergo oxidation. This issue can be affirmed by the small number of samples that showed nonconformity with respect to aldehyde content. Aldehyde poisoning can lead to serious central-nervous-system-related problems such as hangover symptoms, nausea, vomiting, restlessness, sweating, confusion, low blood pressure, rapid heartbeat and headaches. They are usually associated with aldehyde poisoning (Cardoso, 2013).

The esterification reactions are very important in the production of cachaça and distilled spirits. It is a reaction that occurs between ethanol and carboxylic acids present in the beverages, resulting in the formation of esters that are very important for the beverages. Along with esters, higher alcohols, aldehydes and organic acids are responsible for the typical 
(CC BY 4.0) | ISSN 2525-3409 | DOI: http://dx.doi.org/10.33448/rsd-v9i7.4117

aroma and taste of beverages, and they play an important role in the formation of the sensory profile of distillates (Moreira et al., 2012). They are formed during the fermentation process and during the distillation and aging processes. Typically, ethyl acetate represents approximately $80 \%$ of all the esters in cachaça. (Miranda et al., 2008; Cardoso, 2013). This compound, in low concentrations, incorporates a pleasant fruity aroma to the beverage, but, in large quantities, it gives cachaça an undesirable and nauseating taste (Santiago et al., 2016).

The line graphs of the samples analyzed for the contaminant parameters [cu (copper), butil2 (sec-butyl alcohol), butil1 (butyl alcohol), fur (furfural) and met (methyl alcohol)] are presented in Figure 2.

Samples with concentrations of contaminants outside the limit allowed by the legislation were observed for all the contaminants analyzed; however, these results were satisfactory because the number of non-standard samples was very low when compared to the total number of samples under study.

Figure 2. Results of the physicochemical profile for the contaminant contents of the cachaças studied.
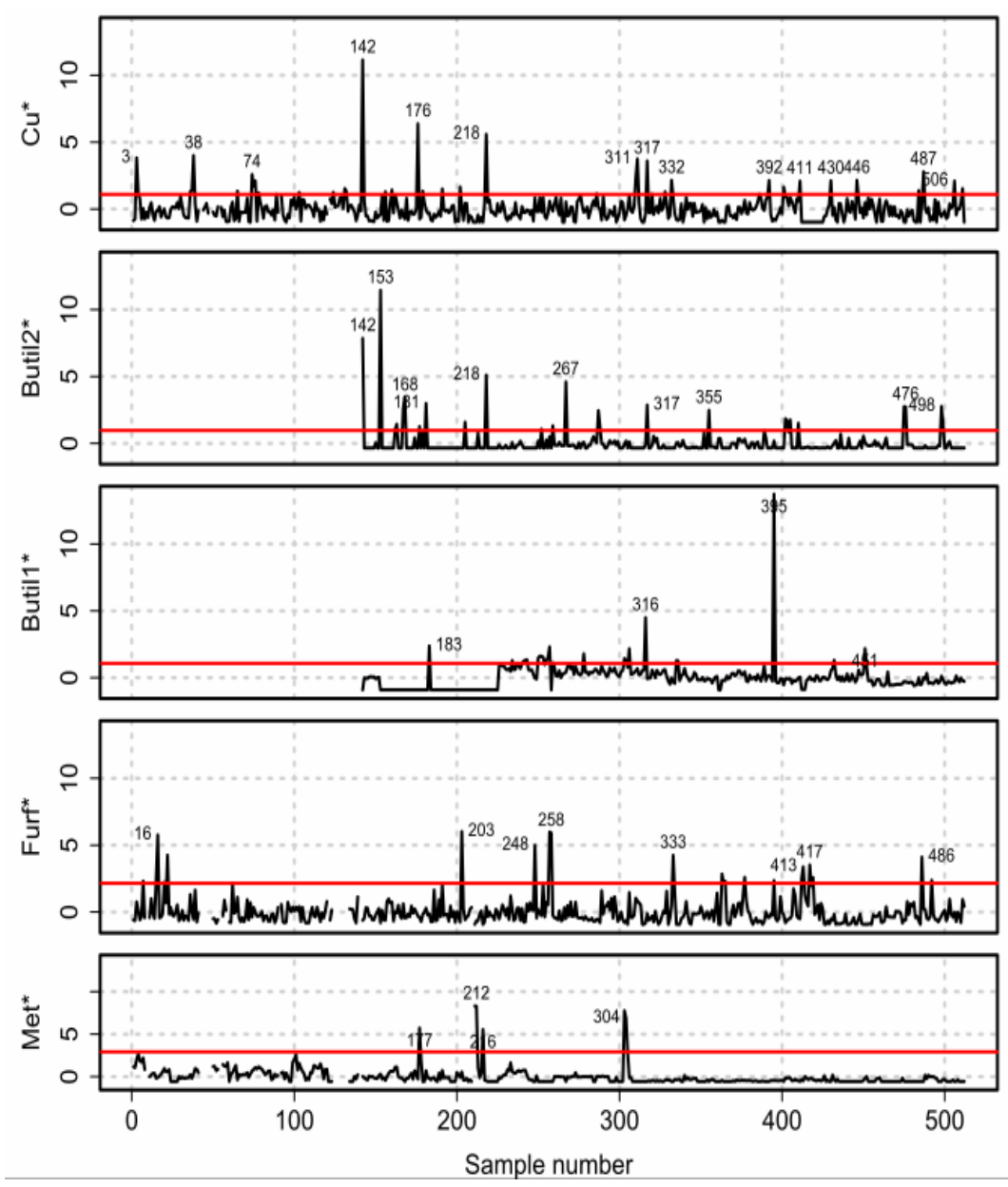
Source: Authors.

The two most commonly used wine distillation processes (fermented must) for the production of cachaça are distillation in a copper still (discontinuous distillation) and column distillation (continuous distillation) (Serafim et al., 2012). Nonconformity regarding the maximum limit for copper of $5 \mathrm{~g} \mathrm{~L}^{-1}$ by the MAPA was observed for only $8 \%$ of the samples, and it can be inferred that they are samples produced in a copper still. The cachaça is distilled in copper stills on a small scale, with an average between 100 and 1000 liters/day, reaching a maximum of 2400 liters. This distillation can be performed in one- or three-body stills (Reche \& Franco, 2009; Cardoso, 2013). The results are satisfactory because they show that the cleaning of the still and the cutting of the distillate are being performed correctly in the production process. In cachaça or spirits, the presence of this metal is mainly due to the dissolution of the basic copper carbonate present on the inner walls of the still, which is carried over by acidic alcohol vapors during distillation. Proper sanitation for removal, as well as filling the still and coils with water to reduce copper oxidation, are measures that considerably reduce the possibility of contamination of cachaça by copper (Cardoso, 2013; Duarte et al., 2014). Santiago et al. (2015) evaluated the profile of cachaça produced in copper stills in the state of Minas Gerais. The acceptability of copper contents ranged from 71 to $88 \%$, and improvements have already been indicated by these results because the acceptability observed in the present study was $92 \%$.

As already mentioned, the higher alcohols are compounds responsible for the organoleptic characteristics of cachaça and spirits. However, Normative Instruction No. 13 of June 2005 included two substances that are higher alcohols, butan-1-ol and butan-2-ol, in the list of CIPs for Sugarcane Spirits and Cachaça, but these alcohols must be quantified separately. The maximum limits for these alcohols are 3 and $10 \mathrm{mg} / 100 \mathrm{~mL}$ of anhydrous alcohol, respectively. This requirement exists because these two organic contaminants are present in beverages (Brasil, 2005a; Santiago et al., 2016).

Butan-1-ol and butan-2-ol are formed in the fermentation stage because of contamination by the bacterium Clostridium acetobutylicum, their toxicities are relatively high compared to that of ethanol. This contamination can be reduced by not leaving sugarcane near stables or milking places and by not using stored sugarcane (Maia \& Campelo, 2006; Cardoso, 2013). Penteado and Masini (2009) analyzed 33 samples of alembic and industrial cachaça produced in four states of Brazil and observed a large variation in the concentration of the higher alcohols in these beverages and a consequent heterogeneity of sensory 
characteristics. The results were significant because the contamination by these substances resulted in $2 \%$ and $5 \%$ non-compliance with the legal limits.

Furfural and methanol are undesirable organic contaminants in alcoholic beverages because they are highly toxic. Furfural is derived from the chemical decomposition of carbohydrates in the production process. The high temperature associated with the low $\mathrm{pH}$ of the wort causes dehydration of sugar and hydrolysis of bagasse polysaccharides (cellulose, hemicellulose, pectin and others) to form 2-furfural (furfural) and 5-hydroxymethyl-2-furfural (HMF). Furfural is formed by the degradation of pentoses, whereas hydroxymethylfurfural is formed from hexoses. Other factors, such as aging of the beverage under irregular conditions, the addition of caramel and pyrogenization of the organic matter deposited in the bottom of the stills can also contribute to the increase in the content of these components (Masson et al., 2007; Zacaroni et al., 2011. ; Moreira et al., 2012; Santiago et al., 2015; Santiago et al., 2016).

Prolonged or repetitive contact with furfural can affect the central nervous system, in addition to producing dermatitis, and mucosal and respiratory irritation. It can also cause headaches, seizures, paralysis, liver and kidney damage, the possibility of carcinogenic effects, dizziness, sore or dry throat and nosebleeds. If swallowed, it causes nausea, vomiting, abdominal pain, diarrhea, coordination disorders, uncontrollable muscle cramps or contractions (Ficha de dados de segurança, 2012). The care with contamination by these contaminants appears to be well established because only $3 \%$ of the samples were contaminated. These results corroborate those of Santiago et al (2015), where the authors found 3.5\% non-compliance for furfural in cachaça produced in Minas Gerais. Bortoletto and Alcarde (2015) evaluated the chemical quality of Brazilian sugarcane spirits and cachaça and found that $2 \%$ of the samples did not meet the limits established by the legislation.

Methanol is an undesirable alcohol in spirits and cachaça. Brazilian law has set a maximum concentration of $20 \mathrm{mg} / 100 \mathrm{~mL}$ of anhydrous alcohol for methanol in cachaça and spirits. Previously, methanol was a major concern on the part of producers and inspectors because its concentration in beverages was significant. However, recent research shows that the concentration has not been above the allowed limit. Zacaroni et al. (2011) characterized and quantified different contaminants in sugarcane spirits, and its presence was not detected. Similarly, Santiago et al. (2014b) did not find methanol concentrations greater than the allowed limit in the cachaça used in their research. These results corroborate those found in this study. 
Overall, the results presented were satisfactory for both the secondary compounds and the contaminants analyzed from the 512 samples. This fact is due to the small volume of samples that presented values outside the limits established by the legislation.

Due to the complexity of the composition of cachaça and the large number of samples, an exploratory statistical study of the samples was performed using PCA. Figure 3 represents the PCs (Principal Components) of the analyzed parameters, which are represented by PC1xPC2. PC analysis was applied for all the parameters analyzed, and secondary compounds and contaminants from samples with all the parameters were analyzed; 370 samples were analyzed in total.

Figure 3. PC1 x PC2 biplot chart of secondary compounds and contaminants analyzed in cachaça

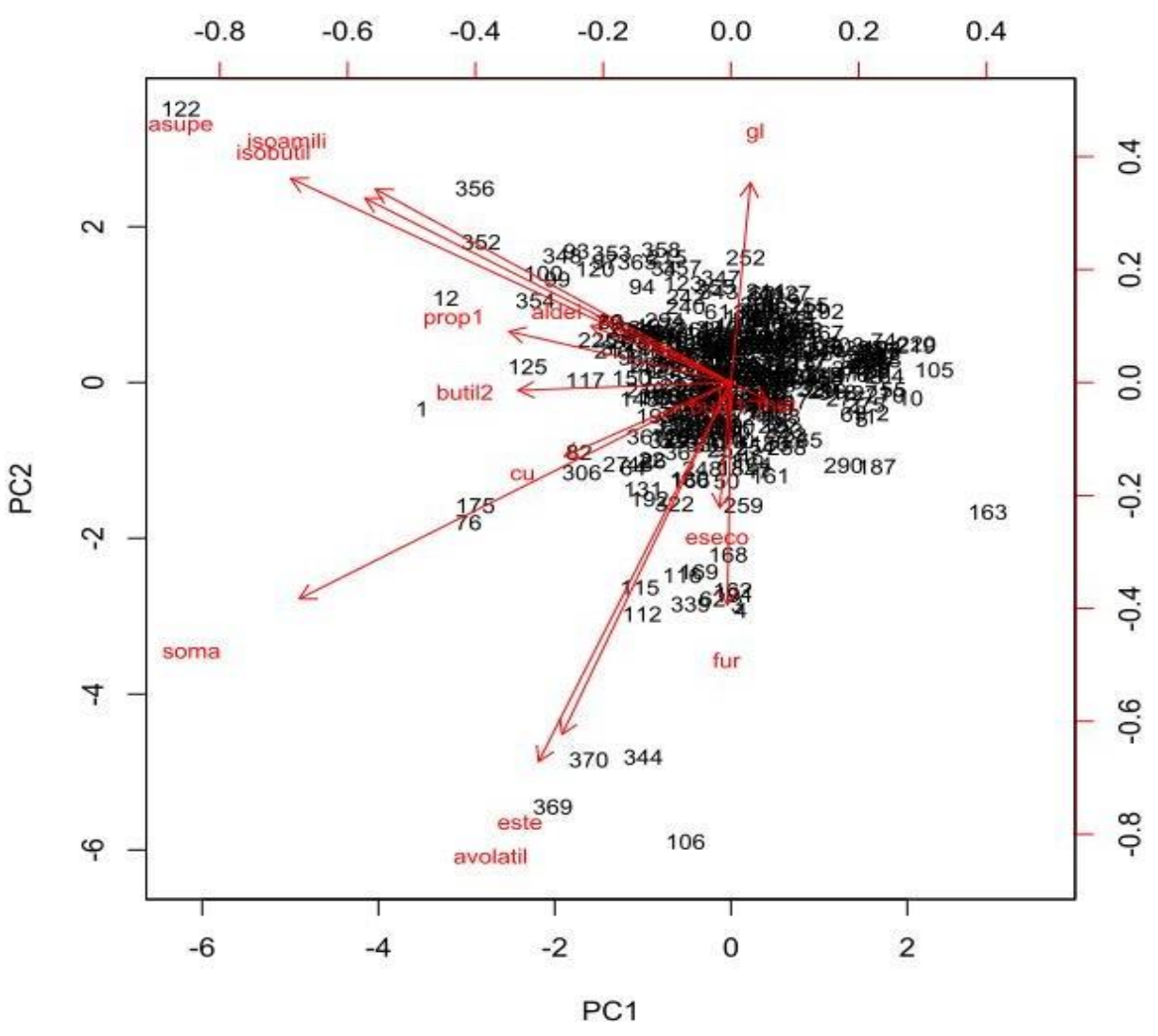

Source: Authors.

The PCA showed that it was possible to describe $76.5 \%$ of the data with the first and second main components. From the PCA on the physicochemical data, one can infer only one grouping, which demonstrates the similarities between the samples. Most samples were concentrated near the origin of the main plane; that is, these variables have a low degree of 
representation. Thus, the cachaça samples in this study tended to be physicochemically homogeneous. These results corroborate those found by Santiago et al. (2015), where the authors used the PCA analysis to evaluate samples of cachaça produced in Minas Gerais, and the authors concluded that the samples produced in that Brazilian state were homogeneous with respect to the physicochemical parameters. Thus, there has been the great evolution in the production of cachaça and spirits in our country, wherein a high quality, standardized product is sought because the principal barrier to exportation is the non-standardization of the beverage.

Improvements in this genuinely Brazilian product can be seen to have occurred over the years when studies in the literature are compared. Stupiello research (1992) concluded that sugarcane spirits produced in Brazil had variations in chemical composition and did not comply with current legislation. In the study by Vargas and Gloria (1995), 65\% of the 511 sugarcane samples produced in the state of Minas Gerais did not meet the quality standards established by Brazilian legislation. Miranda et al. (2007) evaluated 94 cachaça and commercial spirits and reported that $48 \%$ of the samples were not compliant with the legislation with regard to at least one of the components analyzed. Zacaroni et al. (2011) evaluated the presence of organic (furfural, methanol, ethyl carbamate and acrolein) and inorganic (copper) contaminants in sugarcane spirits in the southern region of Minas Gerais, and the authors concluded that $83 \%$ of the beverages were did not meet the quality standards required by MAPA.

Bortoletto and Alcarde (2015) determined the chemical composition of 268 Brazilian cachaças and observed that $50 \%$ of the samples not meeting the quality standards. Finally, Duarte, Cardoso, Santiago, Machado, \& Nelson (2017) evaluated organic cachaças with respect to their physicochemical profile and found that only $26 \%$ did not meet the limits required by MAPA.

In general, the quality of the cachaça depends solely on the sensory properties, where consumers should be pleased, and the chemical composition, when it does not present health risks. It is evident that it has become common for producers to employ good manufacturing practices, seeking a product with high quality and standardization. However, several factors in the production process can be improved. 


\section{Conclusion}

Given the reality regarding the quality of Brazilian cachaça, consumers are becoming increasingly aware and opting for better quality products and standardization.

Cachaça is a typical Brazilian product, previously restricted to a class of low-income consumers, and it has been reaching higher income consumers.

Based on the results, where $70 \%$ of the samples met the quality standards required by MAPA, it is evident that the investment made by the producers in quality control and standardized allows the beverage reach a prominent place in the national and international market.

Multivariate analysis emerges as an important tool in the identification and standardization of Brazilian cachaça regarding its physicochemical profile.

\section{Acknowledgements}

Authors thank the Conselho Nacional de Desenvolvimento Científico e Tecnológico (CNPQ), Fundação de Amparo à Pesquisa do Estado de Minas Gerais (FAPEMIG), and the Coordenação de Aperfeiçoamento de Pessoal de Nível Superior (CAPES) for their financial support and scholarship.

\section{References}

Alcarde, AR, Souza, PA, Bosqueiro, AC \& Belluco, AES. (2009). Perfil físico-químico de aguardente de cana-de-açúcar produzida por metodologias de dupla destilação em alambiqus simples. Alimentos e Nutrição. 20(1), p. 499-506.

Alcarde, AR. (2017). Cachaça - ciência, tecnologia e arte. 2 ed. São Paulo: Blucher.

Bortoletto, AM \& Alcarde, AR. (2015). Assessment of chemical quality of Brazilian sugar cane spirits and cachaças. Food Control. 53(1), p.1-6.

Brasil. (2005a). Ministério da Agricultura, Pecuária e Abastecimento (MAPA). Instrução normativa n.13, de 29 de junho de 2005. 
Brasil. (2005b). Ministério da Agricultura, Pecuária e Abastecimento (MAPA). Instrução normativa n.24, de 08 de setembro de 2005.

Cardoso, MG. (2013). Produção de aguardente de cana. $3^{\mathrm{a}}$ ed. Lavras: Editora UFLA.

Caruso, MSF, Nagato, LAF \& Alaburda, J. (2008). Avaliação do teor alcoólico e componentes secundários de cachaças. Revista do Instituto Adolfo Lutz. 67, p. 28-33.

Duarte, FC, Cardoso, MG, Magriotis, M, Santiago, WD, Mendonca, JGP \& Rodrigues, LMA. (2014). Removal of copper in cachaças using clays. Ciên Agrotecnologia. 38: 382-89.

Duarte, FC, Cardoso, MG, Santiago, WD, Machado, AMR \& Nelson, DL. (2017).

Brazilian organic sugarcane spirits: physicochemical and chromatographic profile. Revista Ciência Agronômica. 48: 288-295.

Ferreira, MMC. (2015). Quimiometria - Conceitos, Métodos e Aplicações. Campinas: Editora UNICAMP.

Fernandes, JF, Cardoso, MG, Vilela, JF, Morais, AR, Silva, VF \& Nelson, DL. (2007). Physicochemical quality of a blend of domestic cachaças from the south of Minas Gerais. Journal Food Compost Anal. 20:(2), p. 57-61.

Ficha de dados de segurança. (2012). Segundo a Directiva 2012/58/CE da Comissão das Comunidades Europeias. Disponível: http://www.furan.com/_resources/downloads/10195pt_rev6.pdf.

Gomes, MCR \& Cavalcante, IN. (2017). Aplicação da análise estatística multivariada no estudo da qualidade da água subterrânea. Revista brasileira de águas subterrâneas. 31(1): 134-149.

Ibrac - Instituto Brasileiro da Cachaça. (2019). Mercado Interno. Brasília.

Maia, ABRA \& Campelo, EAP. (2006). Tecnologia da cachaça de alambique. Belo Horizonte: Sebrae/Sindbebidas, 129p. 
Masson, J, Cardoso, MG, Vilela, FJ, Pimentel, FA, Morais, AR \& Anjos, JP. (2007). Parâmetros físico-químicos e cromatográficos de aguardentes de cana queimada e não queimada. Ciência e Agrotecnologia. 31(6): 1805-810.

Miranda, MB, Horii, J \& Alcarde, AR. (2006). Estudo do efeito da irradiação gamma (60Co) na qualidade da cachaça e no tonel de envelhecimento. Ciência e Tecnologia de Alimentos. 26:(4).

Miranda, MB, Martins, NGS, Belluco, AES, Horii, J \& Alcarde, AR. (2007). Qualidade química de cachaças e de aguardentes brasileiras. Ciência e Tecnologia de Alimentos. 27:(4), p. $897-901$.

Miranda, MB, Martins, NGS, Belluco, AES, Horii, J \& Alcarde, AR. (2008). Perfil físicoquímico de aguardente durante envelhecimento em tonéis de carvalho. Ciência e Tecnologia de Alimentos. 28:(1), p.84-89.

Moreira, RFA, Netto, CC \& Maria, CAB. (2012). A fração volátil das aguardentes de cana produzidas no Brasil. Química Nova. 35:(9), p.1819-1826.

Nieuwoudt, HH, Prior, BA, Pretorius, IS, Manley, M \& Bauer, FF. (2004). Principal component analysis applied to fourier transform infrared spectroscopy for the design of calibration sets for glycerol prediction models in wine and for the detection and classification of outlier samples. Journal of Agricultural and Food Chemistry. 52, p. 37263735 .

Pellenz, JM, Lima, MO, Wobeto, C \& Andrade, RLT. (2017). Cachaça quality assessment produced in northern Mato Grosso. Scientific Electronic Archives. 10:(1).

Penteado, JCP \& Masini, JC. (2009). Heterogeneidade de álcoois secundários em aguardentes brasileiras de diversas origens e processos de fabricação. Química Nova. 32:(5), p. 1212-1215. 
Pereira, NE, Cardoso, MG, Azevedo, SM, Morais, AR, Fernandes, W \& Aguiar, PM. (2003). Compostos secundários em cachaças produzidas no Estado de Minas Gerais. Ciência e Agrotecnologia. 27:(5), p.1068-1075.

Pereira, AS et al. (2018). Metodologia da pesquisa científica. [e-book]. Santa Maria. Ed. UAB/NTE/UFSM. Acesso em: 16 maio 2020. Disponível em: https://repositorio.ufsm.br/bitstream/handle/1/15824/Lic_Computacao_MetodologiaPesquisa-Cientifica.pdf? sequence $=1$.

R core team. (2016). R: A language and environment for statistical computing. $\mathrm{R}$ Foundation for Statistical Computing, Vienna, Austria. URL https://www.R-project.org/.

Rencher, AC. (2002). Methods of multivariate analysis. Nova Iorque: Wiley Interscience.

Reche, R. V \& Franco, D.W. (2009). Distinção entre cachaças destiladas em alambiques e em colunas usando quimiometria. Química Nova. 32, p. 332-336.

Santiago, WD, Cardoso, MG, Gomes, MS, Rodrigues, LMA, Cardoso, RR \& Brandao, RM. (2014a). Correlação entre extrato seco total, composição fenólica total e intensidade de cor de cachaças envelhecidas em tonéis de carvalho (Quercus $\mathrm{sp}$ ) e amburana (Amburana cearensis) em um período de 12 meses. E-xacta. 7, p. 9-15.

Santiago, WD, Cardoso, MG, Santiago, JÁ, Rodrigues, LMA, Silva, BL \& Caetano, ARS. (2014b). Comparação do perfil físico-químico de cachaças envelhecidas em tonéis de carvalho (Quercus sp) e amburana (Amburana cearensis). E-xacta. 7, p.17-29.

Santiago, WD, Cardoso, MG, Zacaroni, LM, Rodrigues, LMA, Duarte, FC, Ribeiro, CFES. \& Nelson. DL. (2015). Multivariate analysis for the characterization of physico-chemical profile of cachaça produced in copper stills on period for six years on Minas Gerais state. Journal of the Institute of Brewing. 121, p. 244-250.

Santiago, WD, Cardoso, MG, Santiago, JÁ, Teixeira, ML, Barbosa, RB, Zacaroni, LM Sales, PF \& Nelson, DL. (2016). Physicochemical profile and determination of volatile compounds in cachaça stored in new oak (Quercus sp.), amburana (Amburana cearensis), 
jatoba (Hymenaeae carbouril), balsam (Myroxylon peruiferum) and peroba (Paratecoma peroba) casks by SPME-GC-MS. Journal of the Institute of Brewing. 122, p. 624-634.

Santiago, WD, Cardoso, MG \& Nelson, DL. (2017). Cachaça stored in casks newly constructed of oak (Quercus sp.), amburana (Amburana cearensis), jatoba (Hymenaeae carbouril), balsam (Myroxylon peruiferum) and peroba (Paratecoma peroba): alcohol content, phenol composition, color intensity and dry extract. Journal of the Institute of Brewing. 123, p.232-241.

Serafim, FAT, Silva, AA, Galinaro, CA \& Franco, DW. (2012). Comparação do perfil químico entre cachaças de um mesmo vinho destiladas em alambiques e em colunas. Química Nova. 35:(7), p. 1412-1416.

Stupiello, JP. (1992). Destilação do vinho. In: Mutton, MJR, Mutton, MA. (Ed.) Aguardente de cana: produção e qualidade. Jaboticabal: FUNEP. p. 67-78.

Vargas, EA \& Gloria, MB. (1995). Qualidade da aguardente de cana (Saccharum officinarum, L.) produzida, comercializada e/ou engarrafada no Estado de Minas Gerais. Ciência e Tecnologia de Alimentos. 15:(1), p.43-46.

Vilela, FJV, Cardoso, MG, Masson, J \& Anjos, JP. (2007). Determinação das composições físico-químicas de cachaça do Sul de Minas Gerais e de suas misturas. Ciência e Agrotecnologia. 31:(4), p.1089-1094.

Zacaroni, LM, Cardoso, MG, Saczk, AA, Santiago, WD, Anjos, JP, Masson, J, Duarte, FC \& Nelson, DL. (2011). Caracterização e quantificação de contaminantes em aguardentes de cana. Química Nova. 34, p.320-324. 
Research, Society and Development, v. 9, n. 7, e387974117, 2020

(CC BY 4.0) | ISSN 2525-3409 | DOI: http://dx.doi.org/10.33448/rsd-v9i7.4117

Porcentagem de contribuição de cada autor no manuscrito

Wilder Douglas Santiago - 35\%

Cleber Nogueira Borges $-15 \%$

Richard Bispo Barbosa - 10\%

Hélia Alves Mendonça - 10\%

David Lee Nelson - 10\%

Maria das Graças Cardoso - 20\% 